\title{
Pengaruh Mutu Pelayanan Terhadap Kepuasan Pasien di Poly Obgyn RSUD.Dr.RM.Djoelham Kota Binjai Tahun 2019
}

\author{
Etika Iskandar Br.Ginting, Sudiro, Tengku Moriza \\ Institut Kesehatan Helvetia \\ Email : etika.iskandargtg@yahoo.com
}

\begin{abstract}
Abstrak
Menurunnya angka kunjungan pasien lama di poliklinik kebidanan dan kandungan untuk 2 - 3 tahun ber turut - turut, salah satu penyebabnya adalah ketidak puasan pasien terhadap pelayanan yang di berikan,Tujuan penelitian ini adalah menganalisis pengaruh dimensi mutu pelayanan terhadap kepuasan pasien rawat jalan di Poliklinik Kebidanan dan kandunganRumahsakit Umum Daerah DR.R.M.Djoelham Kota Binjai pada tahun 2019. Penelitian ini obsevarsional dengan pendekatan waktu cross sectional pengumpulan data dengan survey. Populasi penelitian adalah pasien rawat jalan di poliklinik kebidanan dan kandungan ang mendapatkan pelayan dari dokter SpOG dan diberikan tindakan serta pengobatan yang datang kunjungan untuk pertama kali, Prosedur sampel Accidental Sampling sebanyak n=60t. Hasil sebagian besar responden berumur dewasa awal 18 - 35 th sebanyak 47 orang (78,3\%), berjenis kelamin perempuan 60 orang (100\%), tamatan SMA yaitu sebanyak $40(66,7 \%)$ responden. Ibu rumah tangga sebanyak 49 orang (81,7\%). terdapat hubungan pada dimensi Reliability mempunyai nilai $p=0,0001$, Tangible $p=0,005$, emphaty $p=0,001$, Assurance $p=0,009$, Responsivenes $p=0,004$. Berdasarkan hasil analisis multivariate variabel yang paling besar pengaruhnya terhadap kepuasan pasien adalah variabel Assurance dengan nilai $p$ $=0,012$ dan Exp (B) 6,246. Berdasarkan hasil tersebut disimpulkan bahwa terdapat hubungan dimensi mutu pelayanan terhadap kepuasan pasien. Saran penelitian adala, Di harapkan kepada pegawai khususnya di bagian pendaftaran pasien untuk meningkatkan pelayanan yang cepat dan tepat dalam penerimaan pasien rawat jalan dan Di harapkan untuk petugas yang ada di rawat jalan untuk menggunakan tanda pengenal pada saat bekerja.
\end{abstract}

Kata Kunci : Rawat jalan, Poliklinik kebidanan dan kandungan, dimensi mutu pelayanan , kepuasan pasien

Abstract

One of the causes of patients decrease visitation in obstetrics and gynecology polyclinics for 2-3 years is the patient's dissatisfaction with the services provided. The study aimed to analyze the effect of service quality on outpatient satisfaction at Midwifery Polyclinic of DR.RM. Djoelham Hospital Binjai in 2019. This study was observational with a Cross-Sectional approach. The study populations were outpatients in the obstetrics and gynaecology polyclinic who received services from a SpOG doctor and were given action and treatment for their first visit, the sample were 60 respondents by using accidental sampling. The results showed most of the respondents aged 18 - 35 years of age were 47 respondents (78.3\%), 60 women (100\%), 40 high school graduates (66.7\%) Work as housewives were 49 respondents (81, 7\%). There is a relationship in the Reliability dimension which had a $p$-value $=.0001$, Tangible $p=.005$, Emphaty $p=.001$, Assurance $p=.009$, Responsiveness $p=.004$. Based on the results of multivariate analysis, the variable with the greatest influence on patient satisfaction was the Assurance variable with a value of $p=.012$ and Exp (B) 6.246 . Based on these results it is concluded that there is a relationship between the dimensions of service quality and patient satisfaction. Suggestions are expected to employees, especially in the patient registration section, to improve fast and precise service in the admission of outpatients and it is hoped that outpatient officers use identification marks at work.

Keywords: Outpatient Care, Obstetrics And Gynaecology Polyclinic, Dimensions of Service Quality, Patient Satisfaction.

http://ejournal.urindo.ac.id/index.php/MARSI 


\section{PENDAHULUAN}

Memahami kebutuhan dan keinginan pasien merupakan hal penting yang mempengaruhi kepuasan pasien. Pasien yang puas merupakan aset yang sangat berharga karena apabila pasien merasa puas mereka akan terus melakukan pemakaian terhadap jasa pilihannya, Tetapi jika pasien tidak merasa puas mereka akan memberitahukan dua kali lebih hebat kepada orang lain tentang pengalaman buruknya. Untuk mencapai kepuasan pasien, rumah sakit harus menciptakan dan mengelola suatu sistem untuk memperoleh pasien yang lebih banyak dan kemampuan untuk mempertahankan pasien.

Westbrook \&Reilly Berpendapat bahwa kepuasan pelanggan merupakan respon emosional terhadap pengalaman - pengalaman berkaitan dengan produk atau jasa tertentu. Pelayanan diharapkan membuat pasien merasa puas (customer satification) adalah dengan memberikan kepada pelanggan apa yang benar benar mereka butuhkan dan inginkan, bukan memberikan apa yang kita fikirkan di butuhkan oleh mereka (1)

Kepuasan pasien selain dipengaruhi oleh pelayanan yang diberikan, juga di tentukan Oleh pengalaman dan pemikiran perorangan, dan hal ini tidak dapat dengan mudah diupayakan untuk diubah dan digiring kearah keadaan yang memuaskan. Upaya yang jelas dari pihak rumah sakit agar memberikan pelayanan yang secara konsepsional dan terpadu menjamin kepuasan pada pasien (2)

Ketidak puasan pasien yang paling sering di kemukakan dalam kaitannya dengan sikap dan perilaku pertugas rumah sakit khususnya di rawat jalan, antara lain keterlambatan pelayanan dokter dan perawat, doker sulit ditemui dan lamanya proses pendaftaran pasien, kepuasan pelanggan dipandang sebagai unsur penilaian baik buruknya sebuah rumah sakit. Unsur penentu penilaian baik dan buruknya sebuah rumah sakit ada tiga komponen yang mempengaruhi kepuasan yaitu aspek klinis, efesiensi dan efektifitas, serta keselamatan pelanggan (3)

Dalam mengukur kualitas jasa pelayanan (service quality) dapat di gunakan dimensi kualitas jasa yang di kemukakan oleh Zeithmal
Berry, Parasuraman 1985 kelima karakteristik tersebut adalah tangibles (bukti fisik), realibility(kehandalan), responsivenness ( daya tanggap ), assurance (jaminan) dan empaty (empati) (3).

Pelayanan rawat jalan sering di ibaratkan sebagai "pintu gerbang" bagi rumah sakit. Yang akan mempengaruhi keputusan pasien untuk tetap atau tidak memakai jasa pelayanan rumah sakit tersebut. Bila dalam pelayanan ini, pasien mendapatkan pelayanan prima yang sesuai atau bahkan dapat melampaui harapan pasien, maka akan terbentuk sikap positif terhadap pelayanan rawat jalan ini. Sikap positif akan berpengaruh kepada keputusan pasien untuk melakukan kunjungan ulang ke rumah sakit tersebut,bahkan cenderung akan menjadi pasien yang loyal (4)

$$
\text { Rumah Sakit Umum Daerah }
$$

Dr.R.M.Djoelham Kota Binjai termasuk ke dalam klasifikasi Rumah sakit umum kelas B. Dan rumah sakit ini merupakan salah satu perangkat daerah pemerintah kota Binjai yang di bentuk berdasarkan peraturan daerah kota binjai nomor 16 tahun 2011 tentang organisasi dan tata kerja lembaga teksnis daerah kota Binjai. Jumlah Dokter Obgyn yang terdapat di Poly Obgyn RSUD. Dr.R.M Djoelham Kota Binjai adalah sebanyak 4 oarang. Rumah sakit ini berkomitmen untuk meningkatkan jumlah pasien yang dilayani melalui penerapan standar pelayanan minimal dan peningkatan kualitas serta kuantitas layanan kesehatan dengan mengutamakan keselamatan dan kepuasan pasien (5)

Dari hasil observasi awal yang peneliti lakukan di Poly Obgyn obgyn Pada tanggal 12 Maret 2019 pukul 10.30 WIB di RSUD Dr. R.M. Djoelham Kota Binjai terhadap 10 dari 13 orang pasien menyatakan tidak puas terhadap pelayanan yang di berikan oleh tenaga kesehatan, Pasien mengatakan petugas kesehatan memberikan pelayanan dengan sikap kurang ramah,waktu tunggu pelayanan dokter lambat juga menjadi salah satu keluhan pasien, ruangan poly yang panas, pasien juga mengeluh pada kebersian kamar mandi yang kurang mendapatkan perhatian dari pihak rumah sakit hal ini juga saya lihat sendiri seperti air yang terdapat di bak kamar mandi berawarna kuning, sehingga menimbulkan ketidak puasan pasien 
dan hasil data yang di dapat dari aplikasi Binjai Smart City juga di dapat keluhan keterlamabatan dokter datang ke poly, lamanya layanan admintrasi pendaftaran poly.

\section{METODE}

Penelitian ini merupakan penelitian kuantitatif dengan mengumpulkan data kuantitatif kepada pasien rawat jalan di poly obgyn Rumah Sakit Umum Daerah Dr.RM.Djoelham Kota Binjai dengan menggunakan metode survey analitik yang di lakukan secara cross sectional (6). Penelitian ini di lakukan di Rumah Sakit Umum Daerah Dr.RM.Djoelham Kota Binjai di mulai Desember 2019 sampai dengan selesai, Teknik Pengambilan jumlah sample pada penelitian ini menggunakan Accidental Sampling (7). Sampel pada penelitian ini sebanyak 60 pasien rawat jalan di poly obgyn. Untuk mengetahui variabel mana yang paling berpengaruh terhadap pelayan di Poly Obgyn maka dari itu, data hasil survey dianalisis dengan menggunakan uji Chi-Square dan untuk mengetahui faktor yang paling dominan dalam risiko hipertensi dianalisis dengan menggunakan uji Regresi Logistik.

Tabel 1

Distribusi Karakteristik Responden di Poly Obgyn RSUD.DR.RMDjoelham Binjai

\begin{tabular}{lccc}
\hline $\mathbf{N}$ & Karakteristik & Frekuensi (f) & $\%$ \\
\hline $\mathbf{0}$ & Jenis Kelamin & - & \\
1 & Laki-laki & 60 & 100 \\
\hline 2 & Perempuan & 60 & 100,0 \\
\hline & Total & & \\
\hline & Umur Responden & 47 & 78,3 \\
1 & $18-35$ & 8 & 13,3 \\
2 & $36-45$ & 5 & 8,3 \\
3 & $46-55$ & 60 & 100,0 \\
\hline & Total & 49 & 81,7 \\
\hline & Pekerjaan & 3 & 5 \\
1 & Ibu Rumah Tangga & 2 & 3,3 \\
2 & Pelajar / Mahasiswa & 6 & 10 \\
3 & PNS/TNI/POLRI & 60 & 100,0 \\
4 & Karyawan Swasta & & - \\
\hline & Total & - & 11,7 \\
\hline 1 & Pendidikan & 7 & 66,7 \\
\hline 2 & SD & 40 & 21,7 \\
\hline 3 & SMP & 13 & 100,0 \\
\hline 4 & SMA & 60 &
\end{tabular}

HASIL

1. Analisis Univariat

Berdasarkan tabel 1 mengenai distribusi responden dapat di amati mayoritas responden, berusia (18 - 35) sebanyak 47 orang (78,3\%)

http://ejournal.urindo.ac.id/index.php/MARSI
Sebagian besar responden berprofesi sebagai ibu rumah tangga sebanyak 49 orang $(81,7 \%)$. Dan mayoritas responden, yakni sebanyak 40 orang $(66,7 \%)$ berpendidikan tamat SMA. $(11,7 \%)$. 


\section{Tabel 2}

Tabulasi Silang antara Variabel Reliability Terhadap Kepuasan Pasien di Poly Obgyn RSUD.Dr.RM Djoleham Kota Binjai Tahun 2019

\begin{tabular}{|c|c|c|c|c|c|c|c|c|}
\hline \multirow{3}{*}{ No. } & \multirow{3}{*}{$\begin{array}{l}\text { Variabel } \\
\text { Reliability }\end{array}$} & \multicolumn{4}{|c|}{ Kepuasan Pasien } & \multirow{2}{*}{\multicolumn{2}{|c|}{ Total }} & \multirow{3}{*}{ Sig-P } \\
\hline & & \multicolumn{2}{|c|}{ Puas } & \multicolumn{2}{|c|}{ Tidak Puas } & & & \\
\hline & & $f$ & $\%$ & $f$ & $\%$ & $\mathbf{F}$ & $\%$ & \\
\hline 1 & Baik & 5 & 2.6 & 4 & 15 & 9 & 15 & \\
\hline 2 & Netral & 33 & 55 & 8 & 13,3 & 41 & 68.3 & 0,000 \\
\hline \multirow[t]{2}{*}{3} & Tidak Baik & 1 & 1,7 & 9 & 15 & 1 & 16,7 & \\
\hline & Total & 39 & 65 & 21 & 35 & 60 & 100 & \\
\hline
\end{tabular}

\section{Tabel 2. Analisis Bivariat}

Berdasarkan tabel 2 di atas terlihat bahwa dari 41 responden yang menilai dimensi Reliability pelayanan di poly obgyn netral menilai puas terhadap pelayanan di poliklinik Rumah Sakit Umum dr. Djoelham Kota Binjai sebanyak 33 orang (55\%), sedangkan yang merespon pada dimensi reliability pelayanan poly Obgyn netral namun tidak puas sebanyak 8 orang $(13,3 \%)$. Sedangkan responden yang menilai dimensi reliability pelayanan di poly obgyn baik akan tetapi pasien tidak puas terhadap pelayanan di poly obgyn sebanyak 9 orang $(42,9 \%)$ dan yang menilai dimensi reliability pada pelayanan obgin tidak puas 1 orang $(2,6 \%)$ dan dari 15 responden yang menilai dimensi reliability tidak baik (7.61 \%) menyatakan respon tidak baik terhadap dimensi reliability pelayanan $p$-value 0,000 atau bisa dikatakan kurang dari nilai- $a=0,05$. Sehingga dari uji Chisquare ini memperlihatkan terdapat hubungan antara dimensi Reliability

Tabel 3.

Tabulasi Silang antara Variabel Assurance Terhadap Kepuasan Pasien di Poly Obgyn RSUD.Dr.RM Djoleham Kota Binjai Tahun 2019

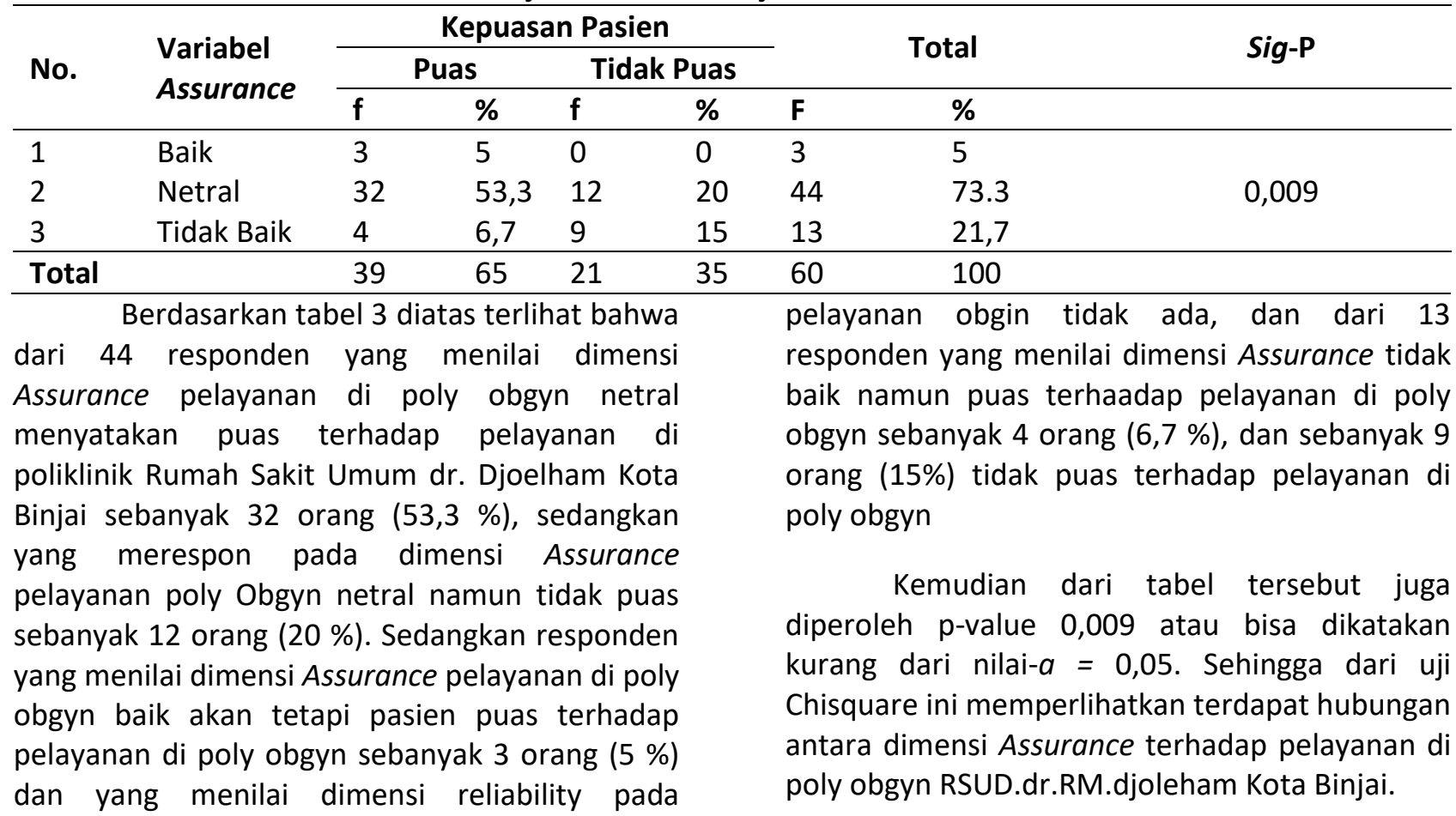


Tabel 4.

Tabulasi Silang antara Variabel Assurance Terhadap Kepuasan Pasien di Poly Obgyn RSUD.Dr.RM Djoleham Kota Binjai Tahun 2019

\begin{tabular}{|c|c|c|c|c|c|c|c|c|}
\hline \multirow{3}{*}{ No. } & \multirow{3}{*}{$\begin{array}{l}\text { Variabel } \\
\text { Tangible }\end{array}$} & \multicolumn{4}{|c|}{ Kepuasan Pasien } & \multirow{2}{*}{\multicolumn{2}{|c|}{ Total }} & \multirow{3}{*}{ Sig-P } \\
\hline & & \multicolumn{2}{|c|}{ Puas } & \multicolumn{2}{|c|}{ Tidak Puas } & & & \\
\hline & & $f$ & $\%$ & $f$ & $\%$ & $F$ & $\%$ & \\
\hline 1 & Baik & 18 & 30 & 6 & 10 & 24 & 40 & \\
\hline 2 & Netral & 17 & 28,3 & 5 & 8,3 & 22 & 36,7 & 0,005 \\
\hline 3 & Tidak Baik & 4 & 6,7 & 10 & 16,7 & 14 & 23,3 & \\
\hline & Total & 39 & 65 & 21 & 35 & 60 & 100 & \\
\hline
\end{tabular}

Berdasarkan tabel 4 di atas terlihat bahwa dari 24 responden yang menilai dimensi Tangible pada pelayanan di poly obgyn Baik dan puas pada poliklinik Rumah Sakit Umum dr. Djoelham Kota Binjai sebanyak 18 orang (30\%), sedangkan yang merespon pada dimensi Tangible pelayanan poly Obgyn Baik namun tidak puas sebanyak 6 orang (10\%). Sedangkan dari 22 responden yang menilai dimensi Tangible pelayanan di poly obgyn Netral akan tetapi pasien puas terhadap pelayanan di poly obgyn sebanyak 17 orang $(28,3 \%)$ dan yang menilai dimensi

Tabel 5.

Tabulasi Silang antara Variabel Emphaty Terhadap Kepuasan Pasien di Poly Obgyn RSUD.Dr.RM Djoleham Kota Binjai Tahun 2019

\begin{tabular}{|c|c|c|c|c|c|c|c|c|}
\hline \multirow{3}{*}{ No. } & \multirow{3}{*}{$\begin{array}{l}\text { Variabel } \\
\text { Emphaty }\end{array}$} & \multicolumn{4}{|c|}{ Kepuasan Pasien } & \multirow{2}{*}{\multicolumn{2}{|c|}{ Total }} & \multirow{3}{*}{ Sig-P } \\
\hline & & \multicolumn{2}{|c|}{ Puas } & \multicolumn{2}{|c|}{ Tidak Puas } & & & \\
\hline & & $f$ & $\%$ & $f$ & $\%$ & $F$ & $\%$ & \\
\hline 1 & Baik & 25 & 41,7 & 9 & 15 & 34 & 56,7 & \\
\hline 2 & Netral & 13 & 21,7 & 1 & 1,7 & 14 & 23,3 & 0,000 \\
\hline 3 & Tidak Baik & 1 & 1,7 & 11 & 18,3 & 12 & 20 & \\
\hline Total & & 39 & 65 & 21 & 35 & 60 & 100 & \\
\hline
\end{tabular}

Berdasarkan tabel 5 di atas terlihat bahwa dari 34 responden yang menilai dimensi Emphaty pelayanan Baik dan puas terhadap pelayanan di Poly Obgyn Rumah Sakit Umum dr. Djoelham Kota Binjai sebanyak 25 orang $(41,7 \%)$, sedangkan yang merespon pada dimensi Emphaty pelayanan Baik namun tidak puas terhadap pelayanan di poly Obgyn sebanyak 9 orang (15\%). Sedangkan dari 14 responden yang menilai dimensi Emphaty pelayanan netral namun puas terhadap pelayanan di poly obgyn sebanyak 13 orang $(21,7 \%)$ dan yang menilai reliability netral tetapi tidak puasa terhadap pelayanan sebanyak $5(8,3 \%)$. Kemudian dari 14 responden yang menilai dimensi tangible Tidak baik dan tidak puas terhadap pelayanan di poly obgyn sebanyak 10 orang $(16,7 \%)$ dan yang menilai dimensi tangible namun puas terhadap pelayanan di poly obgyn sebanyak 4 orang $(6,7 \%)$.

Kemudian dari tabel tersebut juga diperoleh p-value 0,005 atau bisa dikatakan kurang dari nilai- $a=0,05$. Sehingga dari uji Chisquare ini memperlihatkan terdapat hubungan antara dimensi Tangible netral namun tidak puas terhadap pelayanan di poly obgyn sebanyak 1 orang (1,7\%). Sedangkan dari 12 responden yang menilai tidak baik pada dimensi emphaty namun tidak puas terhadap pelayanan sebanyak 11 orang $(18,3 \%)$ dan yang puas terhadap pelayanan di poly obgyn sebanyak 1 orang $(1,7 \%)$

Kemudian dari tabel tersebut juga diperoleh $p$-value 0,000 atau bisa dikatakan kurang dari nilai- $a=0,05$. Sehingga dari uji Chisquare ini memperlihatkan terdapat hubungan antara dimensi emphaty 
Tabel 6.

Tabulasi Silang antara Variabel Responsiveness Terhadap Kepuasan Pasien di Poly Obgyn RSUD.Dr.RM Djoleham Kota Binjai Tahun 2019

\begin{tabular}{|c|c|c|c|c|c|c|c|c|}
\hline \multirow{3}{*}{ No. } & \multirow{3}{*}{$\begin{array}{l}\text { Variabel } \\
\text { responsiveness }\end{array}$} & \multicolumn{4}{|c|}{ Kepuasan Pasien } & \multirow{2}{*}{\multicolumn{2}{|c|}{ Total }} & \multirow{3}{*}{ Sig-P } \\
\hline & & \multicolumn{2}{|c|}{ Puas } & \multicolumn{2}{|c|}{ Tidak Puas } & & & \\
\hline & & $f$ & $\%$ & f & $\%$ & $\mathbf{F}$ & $\%$ & \\
\hline 1 & Baik & 9 & 15 & 2 & 3,3 & 11 & 18,3 & \\
\hline 2 & Netral & 16 & 26,7 & 2 & 3,3 & 18 & 30 & 0,004 \\
\hline 3 & Tidak Baik & 14 & 28,3 & 17 & 23,3 & 31 & 51,7 & \\
\hline Total & & 39 & 65 & 21 & 35 & 60 & 100 & \\
\hline
\end{tabular}

Berdasarkan tabel 4.17 di atas terlihat bahwa dari 31 responden menilai tidak baik pada dimensi Responsivenes dan tidak puas terhadap pelayanan di poly obgyn sebanyak 17 (23,3\%). Sedangkan yang menyatakan puas terhadap pelayanan di poly obgyn sebanyak 14 orang (28,3\%). Sedangkan dari 18 responden menilai netral terhadap dimensi responsiveness dan puas terhadap pelayanan sebanyak $16(26,7 \%)$ dan yang menyatakan tidak puas sebanyak 2 orang (3,3\%). Kemudian dari 11 responden menilai Baik pada dimensi responsiveness dan puas terhadap pelayanan di poly obgyn sebanyak 9 orang (15\%) dan yang menyatakan tidak puas 2 orang $(3,3 \%)$.

Kemudian dari tabel tersebut juga diperoleh $p$-value 0,004 atau bisa dikatakan kurang dari nilai- $a=0,05$. Sehingga dari uji Chisquare ini memperlihatkan terdapat hubungan antara dimensi responsiveness

\section{Analisis Multivariat}

Analisis multavariat menyeleksi variabel yang $\mathrm{p}$ value 0,25 pada uji bivariat (chi-square) dimasukkan secara bersamaan dalam uji multivariat. Kemudian setelah tahap pertama selesai maka variabel yang nilai $p$ value $<0,25$ akan dimasukkan dalam uji multivariat selanjutnya yang bertujuan untuk mengetahui variable mana yang paling dominan memengaruhi kepuasan pasien di poly obgyn Rumah Sakit Umum Daerah dr.Djoelham Kota Binjai Tahun 2019.

Tabel 7

Pemodelan Multivariat Akhir Pengaruh Mutu Pelayanan Terhadap Kepuasan Pasien

\begin{tabular}{lcccc}
\hline Variabel & B & P vlue & Exp(B)OR & 95\%Cl for Exp(B) \\
\hline Assurance & 1,832 & 0,012 & 6,246 & $1,500-26,006$ \\
Emphaty & 1,125 & 0,006 & 3.081 & $1,383-6,865$ \\
\hline
\end{tabular}

Dari analisis multivariat diatas dapat dilihat bahwa analisis regresi logistik menghasilkan 2 variabel yang paling dominan memengaruhi mutu pelayanan terhadap kepuasan pasien di poly obgyn Rumah Sakit Umum daerah dr.RM.Djoelham Kota Binjai Tahun 2019 yaitu variabel Emphaty dengan signifikan
0,006 ( $p$ value $<0,05$ ) OR $=3,081$ yang artinya varibael Emphaty memiliki 3 kali berpengaruh terhadap kepuasan pasien. Dan variabel Assurance dengan signifikan 0,012 ( $p$ value < 0,05) $\mathrm{OR}=6,246$ yang artinya variabel Assurance memiliki 6 kali berpengaruh terhadap kepuasan pasien 


\section{Pengaruh Variabel Reliability terhadap kepuasan Pasien}

Hasil Uji statistic chi square di peroleh $p$ value $0,000<0,005$ yang artinya ada hubungan antara dimensi Reliability terhadap Kepuasan pasien pada pelayanan di poly obgyn RSUD.dr.RM.djoleham Kota Binjai. Dari penelitian ini mayoritas pasien menyatakan netral pada dimensi Reliability Yaitu sebanyak 41 orang $(68,3)$ dan 10 orang pasien menyatakan tidak baik.

Reliability (reabilitas), merupakan kemampuan untuk memberikan pelayanan yang sesuai dengan janji yang di tawarkan. Penilaian kualitas pelayanan dilihat dari kemampuan rumah sakit yang berkaitan dengan ketepatan waktu pelayanan, waktu mengurus pendaftaran, waktu memulai pengobatan/ pemeriksaan, kesesuaian antara harapan dan relasi waktu bagi pasien (11).

Umumnya responden mengatakan perawat jarang menerangkan tindakan yang akan di lakukan ke pasien, dan lebih sering dokter muda yang melakukan tindakan seperti anamnese, tensi, cek suhu tubuh dll dan yang saya dapat Pada saat di lakukan penelitian terlihat dokter sering datang tidak sesuai dengan jadwal yang sudah ada pada hari pertama penelitian, ini kemungkinan disebabkan karena dokter spesialis obgyn lebih mengutamakan melakukan pelayanan terdahulu terhadap pasien - pasien yang ada di gawat darurat, Hal ini dikarenakan pasien yang berobat di poliklinik dianggap bukan termasuk dalam katagori pasien yang harus didahuluan penanganannya. Kemudian penjelasan dokter yang berkaitan dengan diagnosis dan penyakit pasien dinilai tidak baik disebabkan karena banyaknya pasien yang mengantri sehingga membuat waktu yang dimiliki dokter terbatas dalam menjelaskan lebih mendalam terhadap pasien.

Hasil penelitian ini sejalan dengan penelitian yang dilakukan oleh oleh Andini Mentari Tarigan dengan judul penelitian Pengaruh Mutu Pelayanan Tehadap kebaikan Pasien di Poly Rawat Jalan jantung Rumah sakit Advent Kota Medan Tahun 2018 menyatakan bahwa terdapat hubungan yang sangat signifikan menunjukkan bahwa dari 27 pasien yang http://ejournal.urindo.ac.id/index.php/MARSI menyatakan dimensi Reliability Tidak baik dan tidak puas sebanyak 18 orang $(22,5 \%)$ dan tidak puas 9 orang (11,3\%). Dan yang menilai dimensi Reliability Baik dan puas sebanyak 43 orang $(53,7 \%)$ dan yang tidak puas 10 (12,5\%). Dan di dapatkan hasil chi square 0,000 0,0005 maka $\mathrm{HO}$ di tolak yaitu ada hubungan reliability dengan kebaikan pasien di Rumah sakit Advent Kota Medan (8)

Penelitian ini tidak sejalan dengan penelitian yang di lakukan oleh Khairul Ikhsan dan Abdul Karim yang berjudul Analisis Kepuasan Rawat Jalan terhadap pelayanan di RS PKU Muhammadiyah Yogyakarta Periode Maret - Mei 2009 . hasil pnelitian ini menunjukkan bahwa nilai rata - rata kepuasan pasien pada dimensi reliability bahwa dari 30 pasien yang menyatakan dimensi $k u$ Tidak baik dan tidak puas sebanyak 18 orang dan tidak puas 12 orang (9).

\section{Pengaruh Variabel Assurance Terhadap Kepuasan Pasien}

Hasil Uji statistic chi square di peroleh pvalue $0,000<0,005$ yang artinya ada hubungan antara dimensi Reliability terhadap Kepuasan pasien pada pelayanan di poly obgyn RSUD.dr.RM.djoleham Kota Binjai

Dari penelitian ini variabel ini di dapat 44 responden menyatakan Netral pada dimensi Assurance. Dimensi Assurance yaitu kemampuan karyawan atas pengetahuan terhadap produk secara tepat, jaminan keselamatan, keterampilan dalam meberikan keamanan di dalam memanfaatkan jasa yang ditawarkan dan kemampuan dalam menanamkan kepercayaan pelanggan terhadap perusahaan. Dimensi kepastian atau jaminan ini merupakan gabungan dari dimensi kompetensi (compolate), artinya keterampilan dan pengetahuan yang dimiliki oleh para karyawan untuk melakukan pelayanan. Kesopanan (coursty) yang meliputi keramahan, perhatian, dan sikap karyawan.kredbilitas yang meliputi hal - hal yang berhubungan dengan kepercayaan kepada perusahaan seperti reputasi, prestasi dan sebagainya.

Namun 13 pasien juga menyatakan Tidak Baik pada dimensi Assurance ini hal ini saya dapat beberapa pasien yang merasa kurang puas beradasarkan hasil kuesioner di dapat pada 
penerimaan dan pendaftaran pasien pada adminitrasi berlangsung cepat dan tidak terbelit. Responden menyatakan tidak puas terhadap pendaftaran pasien karena berlangsung lumayan lama meskipun loket pendaftaran bpjs dan umum telah di bedakan oleh rumah sakit dan. Bagian farmasi bertanggung jawab apabila ada kesalahan dalam memberikan obat yang di nilai baik oleh responden. Dan karena terkadang adanya dokter muda yang cukup banyak dipoliklinik sehingga terkadang banyak pasien yang merasa kurang nyaman dan malu ketika penyakitnya diketahui oleh orang banyak. Dan yang di rasakan responden juga terbentur dengan waktu pelayanan rumah sakit yang sedikit, membuat pasien kurang puas saat berkonsultasi dengan dokter terhadap penyakit yang dideritanya, di sisilain juga pemahaman pasien yang berbeda sehingga membuat dokter sedikit kesulitan untuk menjelaskan secara detail.

Hasil penelitian ini sejalan dengan peneltian yang di lakukan oleh Ika Cahyaningrum yang berjudul Pengaruh Mutu Pelayanan Kesehatan Terhadap Kepuasan Pasien Rawat jalan Poliklinik Umum Peserta PKMS ( Pemeliharaan Kesehatan Masyarakat Surakarta) di RSUD Kota Surakarta Tahun 2012, adapun hasilnya yaitu pada dimensi Assurance di dapatkan hasil uji Chi-Square yaitu 0,011<0,05 . maka HO di tolak yaitu ada hubungan Assurance dengan kepuasam pasien di RSUD Surakarta (10).

Penelitian ini tidak sejalan dengan penelitian yang di lakukan oleh Eka Masi Lumban yang berjudul Pengaruh Mutu pelayanan Kesehatan terhadap kepuasan pasien rawat inap di Rumah Sakit Pelabuhan Medan ( Prima Husada cipta ) Tahun 2017. Hasil uji chi - square yang di dapat pada penelitian tersebut mendapatkan $0,699>0,005$ artinya tidak terdapat hubungan dimensi assurance terhadap kepuasan pasien rawat inap di rumah sakit pelabuhan medan (11)

\section{Pengaruh Variabel Tangible terhadap Kepuasan Pasien}

Hasil Uji statistic chi square di peroleh $p$ value $0,005<0,05$ yang artinya ada hubungan antara dimensi Tangible terhadap Kepuasan pasien pada pelayanan di poly obgyn RSUD.dr.RM.djoleham Kota Binjai

Tangibles ( tampilan / bukti fisik) merupakan wujud kenyataan secara fisik yang meliputi penampilan dan kelengkapan fasilitas fisik seperti ruang perawatan, gedung dan ruangan front office yang nyaman tersedianya tempat parkir, keberisihan, kerapihan dan kenyamanan ruang tunggu dan ruang pemeriksaan kelengkapan peralatan, komunikasi serta penampilan (12).

Namun 22 orang pasien menyatakan netral dan 14 orang pasien menyatakan tidak baik berdasarkan hasil kuesioner di dapatkan Petugas farmasi menuliskan aturan pakai obat yang mudah di mengerti namun responden juga mengatakan meskipun sulit di mengerti petugas farmasi mau menjelaskan aturan pakai obat,pada saat penelitian saya melihat masih ada beberapa pegawai yang tidak menggunakan tanda pengenal. Ruang tunggu pasien di poly obgyn yang cukup panas dan pengap karena kipas angin yang tidak hidup ruangan tunggu di poly obgyn yang sangat sempit, kamar mandi yang ada di poly RSUD,RM.DR.Djoelham Kota Binjai lumayan bersih namun ada beberapa pasien yang menyatakan terkadang air berawarna kuning dan tidak bersih.

Hasil penelitian ini sejalan dengan penelitian yang di lakukan oleh Sarma Eko Natalia sinaga yang berjudul Pengaruh Mutu Pelayanan Terhadap Persepsi Pasien di Rumah Sakit Misi Lebak Banten Tahun 2017 hasil yang di dapat ada seanyak 7 orag $(8,4 \%)$ pasien yang mendapatkan tangibles kurang baik memiliki persepsi yang baik terhadap mutu pelayanan rawat jalan. Dan hasil uji statistic di peroleh nilai $p$ - value $0,000<$ 0,0005 maka HO di tolak yaitu ada hubungan tangible dengan Persepsi pasien di Rumah Sakit Misi Lebak Banten Tahun 2017 (11).

Hasil penelitian ini sejalan dengan penelitian yang di lakukan Ani Sepatiani yang berjudul Pengaruh Faktor - faktor Kualitas pelayanan terhadap kebaikan pasien di Instalasi Gawat Darurat RSUD Kabupaten Sumedang Hasil penelitian menunjukkan uji chi square 0,000 < 0,05 karena nilai $p$ kurang dari 0,05 yang berarti terjadi penolakan hipotesis null sehingga hasil tersebut signifikan. Semakin tinggi tingkat 
tangible maka semakin tinggi tingkat kebaikan pasien terhadap pelayanan (13).

\section{Pengaruh Variabel Emphaty terhadap kepuasan pasien}

Hasil Uji statistic chi square di peroleh pvalue $0,000<0,005$ yang artinya ada hubungan antara dimensi Emphaty terhadap kepuasan pasien pada pelayanan di poly obgyn RSUD.dr.RM.djoleham Kota Binjai

Dari penelitian ini variabel ini di dapat 34 responden menyatakan Baik pada dimensi Empathy. Dimensi emphaty ini merupakan penggabungan dari dimensi akses (acces) meliputi kemudahan untuk memanfaatkan jasa yang di tawarkan perusahaan. Komunikasi untuk menyampaikan informasi kepada pelanggan dan memahami kebutuhan dari pelanggan. Berdasarkan hasil kuesioner mayoritas responden menyatakan tidak setuju pada Petugas kesehatan mengenakan tanda pengenal yang jelas. Pada saat penilitian berlangsung saya mendapati pegawai dan petugas kesehatan masih ada beberapa pegawai yang tidak menggunakan tanda pengenal,

Hasil penelitian ini sejalan dengan penelitian yang dilakukan oleh oleh Andini Mentari Tarigan dengan judul penelitian Pengaruh Mutu Pelayanan Tehadap kebaikan Pasien di Poly Rawat Jalan jantung Rumah sakit Advent Kota Medan Tahun 2018 menyatakan bahwa terdapat hubungan yang sangat signifikan menunjukkan hasil uji statistic chi square di peroleh nilai $p=0,009<0,05$ yang artinya ada hubungan indikator emphaty dengan kebaikan pasien (8).

Penelitian ini tidak sejalan dengan penelitian yang di lakukan oleh Eka Masi Lumban yang berjudul Pengaruh Mutu pelayanan Kesehatan terhadap kepuasan pasien rawat inap di Rumah Sakit Pelabuhan Medan ( Prima Husada cipta ) Tahun 2017. Hasil uji chi - square yang di dapat pada penelitian tersebut mendapatkan $0,231>0,005$ artinya tidak terdapat hubungan dimensi Emphaty terhadap kepuasan pasien rawat inap di rumah sakit pelabuhan medan (11).

Pengaruh Variabel Responsiveness terhadap kepuasan pasien

Hasil Uji statistic chi square di peroleh $p$ value $0,004<0,005$ yang artinya ada hubungan antara dimensi Responsivenes terhadap kepuasan pasien pada pelayanan di poly obgyn RSUD.dr.RM.djoleham Kota Binjai

Respons atau kesigapan karyawan dalam membantu pelanggan dan memberikan pelayanan yang cepat dan tanggap yang meliputi kesigapan karyawan dalam melayani pelanggan, kecepatan karyawan dalam menangani transaksi dan penanganan keluhan pelanggan atau pasien (1).

Dalam penelitian ini mayoritas responden yang memberikan persepsi Tidak baik pada dimensi responsivenes yaitu sebanyak 31 orang $(51,7 \%)$ dan yang memberikan persepsi netral yaitu sebanyak 18 orang (30\%). Dan minoritas persepsi responden yang memberikan persepsi baik sebanyak 11 orang (18,3\%). Hal ini wajar dilakukan oleh pasien karena setiap pasien yang melakukan pengobatan akan selalu mempunyai keinginan dilayani paling awal, dan merasa bosan ketika menunggu antrian khususnya di bagian pendaftaran di Poly Obgyn. kemudian pasien juga menyatakan setuju pada Petugas bagian pendaftaran menangapi pasien secara tepat dan cepat dan Perawaat segera mengecek tekanan darah pasien sebelum dokter datang

Hasil penelitian ini sejalan dengan penelitian yang di lakukan oleh Sarma Eko Natalia sinaga yang berjudul Pengaruh Mutu Pelayanan Terhadap Persepsi Pasien di Rumah Sakit Misi Lebak Banten Tahun 2017 hasil yang di dapat ada seanyak 7 orang $(9,1 \%)$ pasien yang mendapatkan Responsiveness kurang baik memiliki persepsi yang baik terhadap mutu pelayanan rawat jalan. Sedangkan di antara pasien yang mendapartkan rensponsiveness baik ada $14(42,4 \%)$ yang memiliki persepsi baik terhadap mutu pelayanan. Dan hasil uji statistic di peroleh nilai $p$ - value $0,000<0,0005$ maka $\mathrm{HO}$ di tolak yaitu ada hubungan responsiveness dengan Persepsi pasien di Rumah Sakit Misi Lebak Banten Tahun 2017 (14). 


\section{Pengaruh Mutu Pelayanan Terhadap Kepuasan Pasien}

Pemantauan dan pengukuran terhadap kepuasan konsumen telah menjadi kebutuhan mendasar bagi setiap penyedia jasa. Hal ini dikarenakan langkah tersebut dapat memberikan umpan balik dan masukan bagi keperluan pengembangan dan implentasi strategi peningkatan kepuasan konsumen. Pada prinsipnya kepuasan konsumen dapat diukur dengan berbagai macam metode dan teknik (15).

Hasil analisis multivariat dari penelitian ini menunjukkan bahwa dimensi Assurance

\section{KESIMPULAN}

Dari penelitian ini dapat disimpulankan bahwa :

1. Terdapat Hubungan yang signifikan antara variabel dimensi Reliability dengan Kepuasan pasien di Poly Obgyn Rumah Sakit Umum Daerah DR.RM.Djoelham Kota Binjai .

2. Terdapat Hubungan yang signifikan antara variabel dimensi Assurance dengan Kepuasan pasien di Poly Obgyn Rumah Sakit Umum Daerah DR.RM.Djoelham Kota Binjai .

3. Terdapat Hubungan yang signifikan antara variabel dimensi Tangible dengan Kepuasan pasien di Poly Obgyn Rumah Sakit Umum Daerah DR.RM.Djoelham Kota Binjai . merupakan dimensi yang dominan berpengaruh terhadap kepuasan pasien di Poly Obgyn RSUD.DR.RM.Djoelham Kota Binjai Walaupun pada hasil penelitian ini tidak semua responden yang menilai baik pada dimensi Assurance tersebut, akan tetapi jika dilakukan penilaian secara bersamaan maka dimensi tersebut merupakan dimensi yang berhubungan dengan kepuasan responden dan memiliki pengaruh dominan terhadap Dapat di lihat dari hasil variabel Dimensi Assurance dengan signifikan 0,012 ( $p$ value $<0,05$ ) OR $=6,246$ yang artinya varibael Assurance memiliki 6 kali berpengaruh terhadap kepuasan pasien. di poly Obgyn.

4. Terdapat Hubungan yang signifikan antara variabel dimensi Emphaty dengan Kepuasan pasien di Poly Obgyn Rumah Sakit Umum Daerah DR.RM.Djoelham Kota Binjai .

5. Terdapat Hubungan yang signifikan antara variabel dimensi Responsiveness dengan Kepuasan pasien di Poly Obgyn Rumah Sakit Umum Daerah DR.RM.Djoelham Kota Binjai .

6. Pada penelitian ini dimensi Emphaty merupakan variabel dimensi yang mempengaruhi kepuasan pasien di Poly Obgyn Rumah Sakit Umum Daerah DR.RM.Djoelham Kota Binjai . 


\section{DAFTAR PUSTAKA}

1. Wetsbrook,R.A \& Reilly M. Value Percept disparity an alternative to the disconfirmation of expectations theory of consumer satisfaction. 1983;10:256-61.

2. Sabarguna B. Pemasaran Pelayanan Rumah Sakit. Jakarta: CV Sagung Seto; 2008.

3. Parasuraman A. A Conceptual Model of Service Quality and its implication for future Research. J Mark. 1985;49:41-50.

4. Muwarni A. Cara mudah memahami manajemen kesehatan dan rumah sakit. Sleman, Yogyakarta: Gosyen Publish; 2012.

5. Kusumapradja RNP. Analisis Hubungan Antara Kualitas pelayan, karakteristik pasien, dan Hambatan Loyalitas Pasien Rawat Jalan RSUD Cibinong. Jakarta; 2013.

6. Nursalam. Konsep dan Penerapan Metodologi Penelitian IImu Keperawatan. Jakarta: Salemba Medika; 2008.

7. Sugiyono. Metode Penelitian Kualitatif Dan Kuantitatif. Jakarta: Alfabeta; 2012.

8. Tarigan AM. Pengaruh Mutu Pelayanan Terhadap Kebaikan Pasien di Poly Jantung Rawat Jalan Rumah Sakit Advent Medan. Medan; 2018.

9. Khairul ikhsan AK. Analisaa kepuasan Pasien Rawat Jalan Terhadap Pelayanan di RS PKU Muhammadiyah Yogyakarta Periode Maret - Mei 2009. Yogyakarta; 2009.
10. Ika Cahyaningrum. Pengaruh Mutu Pelayanan Kesehatan Terhadap Kepuasan Pasien Rawat Jalan Poliklinik Umum Peserta PKMS Di RSUD Kota Surakarta [Internet]. surakarta; 2012. Available from:

http://eprints.ums.ac.id/22306/25/NASKA H_PUBLIKASI.pdf

11. Eka Masi Lumban Toruan. Pengaruh Mutu Pelayanan kesehatan terhadap kepuasan pasien rawat inap di rumah sakit pelabuhan medan ( Prima Husada Cipta) Tahun 2017. Medan; 2017.

12. Herlambang S. Manajemen Pelayanan Kesehatan Rumah Sakit. In Sleman, Yogyakarta: Gosyen Publish; 2016.

13. Ani Septiani. Pengaruh Faktor - faktor Kualitas pelayanan Terhadap kepuasan Pasien di Instalasi Gawat darurat RSUD Kabupaten Sumedang. Sumedang; 2016.

14. Sarma Eko Natalia Sinaga. Pengaru Mutu pelayanan Rawat Jalan Terhadap Persepsi Pasien/ Keluarga di RS Misi Lebak Banten. Banten; 2017.

15. Sari ID. Manajemen Pemasaran Usaha Kesehatan. Yogyakarta: Nuha Medika; 2010. 